Published on Reviews in History (https://reviews.history.ac.uk)

\title{
The Emergence of a National Market in Spain, 1650-1800: Trade Networks, Foreign Powers and the State
}

Review Number: 2088

Publish date: Thursday, 6 April, 2017

Author: Guillermo Pérez Sarrión

ISBN: 9781472586476

Date of Publication: 2016

Price: $£ 69.99$

Pages: 368pp.

Publisher: Bloomsbury

Publisher url: http://www.bloomsbury.com/uk/the-emergence-of-a-national-market-in-spain-1650-1800-978147258

Place of Publication: London

Reviewer: Agustín González Enciso

The formation of a national market has long been a classic theme of economic history. At the moment it has fallen slightly out of fashion, and researchers' eyes have been caught by other issues, but this is by no means because the theme per se has lost importance. In Spain's case the study of the historical formation of the national market remains unfinished business, with a few partial studies but no systematic and thoroughgoing analysis. Pérez Sarrión's book does not fill the gap completely but it is a good start, studying as it does a series of general and particular aspects of the interior market against the backdrop of the problem of the formation of the national market.

The main aim of the work is to challenge the overly simplistic view that a Spanish national market emerged in the 19th century as a consequence of the development of the railways. In fact, a national market had been forming for some time and was clearly discernible a century prior to this. Pérez Sarrión argues that a unified market cannot be explained solely by price convergence; there are other extremely significant factors. The author goes back to the mid-17th century to pick up on some of these, including the international powers' interest in the Spanish market and the formation of networks of foreign and Spanish merchants, which plugged into migratory processes, especially of French nationals, already underway in Spain. The historical outlook this study provides shows not only that these factors were operative prior to 1700 but also their growing importance thereafter. After that date two key factors were changes occurring at the start of the 18th century, firstly as a result of the War of the Spanish Succession and the consequent switch in Spain's geostrategy, and secondly following the accession of the new Spanish Bourbon dynasty, which came in with a new-broom attitude to trading legislation.

The book stresses that 'national' market, is to some extent an anachronistic term, more applicable to the 19th century, as Spanish trade in the 18th century still had to cope with the many legal differences between the different territories of Spain at the time, despite the unifying legal changes brought in. A telling fact here is that the title of the work in Spanish refers to the 'Península comercial' (trade on mainland Spain) rather than an emerging national market as per the English version. There is nothing to be said against the new title, other than to remember that the ostensible Spanish 18th-century nation was still a conglomerate of different jurisdictions. This was particularly true of the northeast corner of Spain (Aragón, Catalonia, Navarre and the 
Basque Country), to which Pérez Sarrión devotes the core of his reflections, a territory divided off from Castile by a host of different taxation and custom systems; nonetheless, as Pérez Sarrión shows, the differences did not stop these territories and indeed the whole of Spain from forming wide-ranging zones in which a unified market did operate, that is, a market in which there was a routine toing and froing of merchandise, between established companies and mercantile networks, with known market prices for staples synchronised among relatively far-off trading sites. Regional legal differences were therefore a handicap but were not insurmountable.

To account for this, the author invokes the concepts of urban systems and economic networks already applied by Ringrose to 18th- and 19th-century Spain.(1) Pérez Sarrión hones these ideas and grounds them more closely in the empirical evidence (p. 18). The book's first chapter 'The concepts: market, regions, networks and state' is particularly important, because it defines these terms precisely from a theoretical perspective, which the author proves himself to be very familiar with, but always in reference to the situation in 18th-century Spain. This brings the concepts to life, with a more clearly defined scope and applied to a specific historical situation.

As for its empirical content, the book can be divided into three parts, corresponding to a similar breakdown in the author's study of the interior market: Foreign powers (chapters two, three and four), the state (chapter five) and trade networks (chapters six and seven). These three themes form the subtitle of the book, albeit expressed there in a different order to their treatment within the text. It is not clear if this order change was a mere coincidence or if it expresses the author's desire to stress the fact that all this trade was only possible, in the last analysis, due to the intersection of networks - personal relationships in short - at different levels. This idea crops up time and time again in the text, referring to a reality that is taken for granted.

Although these three themes are naturally distinct, and require a different methodological approach, they are also related. Regarding foreign powers, the author poses three questions: who are they, what interest do they have in the Spanish market and how do they operate? The foreign powers, in any case, boil down to France and England (Great Britain). Chapter two sets out to demarcate them. It is a synthesis of the economic capacities of each country, a comparative study that comes into its own in terms of the policies studied afterwards. Here we see the growth of two different economic worlds as from c. 1650; both of them grappling with a growing rivalry in general and also interested for different reasons in the Spanish market. This market can in some ways be said to have become unified precisely insofar as it is the object of the trading interest of the foreign powers. The chapter comes out a very synthetic bibliographical study, coming across as convincing even though the material tapped into is not abundant. It is surprising, in particular, that more French-language works are not drawn from in this chapter; most of what is said about France is in fact based on works written in English.

Chapters three and four study French-English rivalry over the Spanish market in two periods: 1650-1715, and 1715 onwards. It is not so much a question of the tug o' war between them but rather their endeavours to win better trading relations with Spain compared to their rival. This is a diplomatic study analysing the texts of the treaties and reports of consuls and ambassadors. A factor brought out here is the intimate relation between foreign trade and interior trade, since imported goods, once inside Spain, become part of interior trade. It confirms that 'all consumption is interior trade' (2); even so, Pérez Sarrión is interested in the people bringing these goods in from outside. This process was different in both cases: English traders stopped at the seaports, whereas French traders, with more political and religious affinities and faculties, also set up business inside Spain. The sheer abundance of French emigrants in Spain also favoured the formation of Frenchmen-only networks. Chapter three (1650-1715) shows clearly that this foreigner-driven, importation-based trading relation, circulating through different networks, was already gelling well before the 18 th century.

Particularly interesting here is the author's analysis of Spain's diplomatic relations with the aforementioned countries, which involves studying the treaties of 1659 with France and 1667 with England, and bringing out the respective advantages and disadvantages of both countries in their trade with Spain. The French came off 
better after 1659, despite the fact that Louis XIV's policies drew them away from Catalonia. From 1667, however, England managed to bring its traders' legal situation into line with thopse of France; its trade with Spain then grew in the 1680s and built up an absolute pre-eminence over Spain itself in their bilateral trading relations. The reader is reminded here that those with interest in the Spanish market had the ulterior motive of trading with Spanish America, with Spanish traders acting as middlemen, although the author does tend to concentrate on his main remit: the legal conditions of trade within Spain.

The Spanish War of Succession changed the situation temporarily. At least up to 1709 the French obtained a clear advantage in trading relationships with the Spanish market but the treaties of Utrecht, recognised by Spain in 1714, restored the situation to its former state. Pérez Sarrión studies the treaties in detail to bring out not only the best known Spanish concessions like the navio de permiso (the right to send one ship a year to Spanish America) and the asiento de negros (a contract for supplying African slaves to the Spanish colonies in the Americas) but also the agreements regulating trade between Spain and Great Britain, specifically customs duties and tariffs. In doing so the English forced the reorganisation of the Spanish customs system. Unified customs duties were not actually created until 1782, but the ten tariff was applied to imports and exports throughout the 18th century (pp. 79-80).

During the 18th century (chapter four), both countries trading relations with Spain were fairly equivalent. The author pays close attention to naturalisation laws, which created different conditions for traders, each one trying to exploit his own situation as he could. Apart from that, the French found advantages in their political alliance, in the existence of numerous emigrant networks, in the dressing fashion of the time and in the presence of a financial elite in Madrid. Great Britain, on the other hand, seemed to have the edge in Cádiz and other ports, although their merchants were harder put to trade within Spain. As for products, British textiles boasted a market advantage in terms of technical superiority and raw materials, while the French benefited from lower wages paid to textile workers. In short the relative advantages more or less cancelled out. What stands out here is the interest of both powers in Spain's interior market and their rivalry, shown in the various strategies explained in the book. Some information, however, is missing. The ambassadors' opinions are stated and seem to be very reasonable in all cases, chiming in with what we know in general about Spain's oversees trade; nonetheless, some figures to confirm these countries' trading trend in Spain would not have come amiss.

The active trading policies pursued by France and England from 1650 provoked a response from the Spanish state, which became clearer and more decided after the end of the War of Succession. Chapter five, 'The Enlightenment state and reform', is a study of the different aspects of the state's reforming activities. Trading networks needed encouraging and the state obliged, thus improving market conditions. This chapter is basically a study of the legislation, a precise and sober section limited to questions relating to interior trade. Points brought up are political and taxation reform, customs policy and monetary policy (money, debt, censuses), especially in the first half of the century. There is an interesting nod towards national and foreign identity, which impinged so heavily on trade, especially in the second half of the century. Drawing on existing literature, the author appraises the results of this policy. As he himself acknowledges, many of the points he makes are already well known, others not so; in summary, the overall picture is one of a 'sustained reformism' which is appraised fairly positively: 'The states' policies were in many cases remarkably successful, creating more favourable conditions for trade and the development of economic regions' (p. 161).

The scene is now set for a more specific study of how trading networks, ostensibly favoured by these policies, actually grew. This is the subject of the last two chapters, which are essentially two case studies,. Featuring prominently in this analysis are the French emigrants, either due to their sheer abundance throughout Spain and in particular in Navarre (chapter six), or due to their absence in the case of Catalonia (chapter seven). Navarre is an idiosyncratic case; as a region it was divided off from its Spanish neighbours by many customs duties but it was on the other hand open to free trade with France. Frenchmen also found it easier to naturalise themselves there, unlike in the Basque provinces. The upshot was a heavy French presence in Navarre and a strong trading relationship with Bayonne. French presence was also notable in Aragon, albeit for different reasons; in particular, the loss of fueros (regional charters) during the War of the 
Spanish Succession wiped out the strong protectionist measures that Aragon had brought in during the 17th century. Finally the author makes some brief mention of French presence in other parts of Spain.

The last chapter changes tone. The star turns of the Catalonia market are not the French but rather the Catalans who, thanks to the government's customs policy, were able to make heavy inroads into the rest of Spain, especially Aragon. The author pays special attention to some Catalan companies working in various fields in Aragon and Catalonia, drawing on previously unpublished material. Here the study focuses more on the last third of the 18th century, lingering on into the first years of the 19th, showing that after the War of Independence there was less trading discontinuity that had previously been thought.

Three conclusions to wind up. The first is that the geographical area under survey seems to be voluntarily hemmed in. Aspects pertaining to overseas trade have a general scope but aspects of the state's economic policy and legislation focus on the policy of abolishing inland customs duties that had divided Castile off from the various fuero-bearing regions to the north. In this sense the study centres on the integration of Aragon in the Castilian market, undoubtedly of crucial importance. Other questions of a wider scope are not studied in detail, although they do help to frame the general problem.

The second conclusion, a consequence of the first, refers to the importance given in this work to Aragon, which is in fact one of the lodestars of the study. It is a central territory in northeast Spain and, despite the Pyrenees, was always an important passage point for the French into Spain. Pérez Sarrión's work thus does justice to the importance of this territory's trading role in general and Zaragoza in particular.

The third conclusion, finally, refers to the results of the reformist policy. Interpretations of Spain's enlightened reforms range from the traditional, emphasising the abundant legislation and taking social transformation for granted, to those that denounce the reformers' failure in light of Spain's poor response capacity to the crisis of the French Revolution. To my mind, Pérez Sarrión takes up a reasonable middle road. He stresses the work of the state, not in terms of its simple legislative bent but rather its political will to come up with a necessary response by Spain to the 'difficult commercial relations with England and France' (p. 26). This was no easy task.

'The Spanish state had been seriously weakened in the seventeenth century and it was able to afford only limited protection and support for the development of the interior market. After the War of Succession, however, the state underwent a process of far-reaching reforms, which took decades to complete but eventually allowed the implementation of an actively mercantilist economic policy' (p. xvi).

According to the author this activity certainly occurred, even if the result of it varied according to circumstances. These words, in any case, are less effusive than those quoted earlier (reference to p. 161), and the moot point is perhaps that if the reforms were not brought in for decades, how far was the new state was able to make up for lost time (p. 22).

Together with the state, a key role here is played by private traders, who, well organized in networks, mobilised merchandise and capital and sought leverage for improvement in current legislation. The book tells us quite a bit about the networks of French immigrants and traders and touches on the Catalans towards the end but makes no mention of other possible groups and territories. In any case, to what extent did private traders drive the improvements? The impression we get from the book is that politicking was very important; there was certainly an increase in activity thanks to growing private activity but this fed on political and legislative changes. 
In short, the book contains a lot of useful information and insights and makes a significant contribution to our knowledge of Spain's interior market. A final section of general conclusions would have been welcome, as would a detailed map for readers not familiar with Spanish geography.

\section{Notes}

1. David Ringrose, Spain, Europe and the 'Spanish miracle', 1700-1900 (Cambridge, 1996).Back to (1)

2. Agustín González Enciso, 'El comercio en la España interior durante la Época Moderna', in Obradorio de Historia Moderna, 17 (2008), 17.Back to (2)

Source URL:https://reviews.history.ac.uk/review/2088

\section{Links}

[1] https://reviews.history.ac.uk/item/206076 